\title{
FACTORS INFLUENCING THE FINANCIAL POTENTIAL OF CORPORATE INNOVATIVE DEVELOPMENT
}

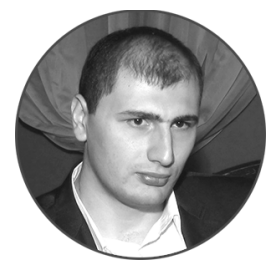

Article history: Received 24 March 2017 Received in revised form 25 May 2017

Accepted 9 June 2017

Translated 20 April 2018

Available online 27 June 2018

JEL classification: G17, G31

Keywords: factor, financial potential, financial capacity, innovative development

\author{
Ayaz A. ALIEV \\ Plekhanov Russian University of Economics, Moscow, Russian Federation \\ ayaz.797@mail \\ https://orcid.org/0000-0003-1476-9702
}


According to the contemporary dictionary of economics, factors shall mean conditions, reasons, parameters, indicators, which have an impact and effect on an economic process and respective results ${ }^{2}$.

Authors referred to herein [1] enumerate some factors at the regional level, which are believed to have the strongest effect on the innovative development mechanism. The financial mechanism for innovative development depends on the factors below to the greatest extent:

- resources, raw materials (weighted average endowment of reserves of key natural resources);

- production (comprehensive result of business activity in the region);

- consumption (gross purchasing power of the region's population);

- infrastructure (economic and geographic position and sufficiency of available infrastructure);

- knowledge (educational background of the population);

- institutions (development level of leading market institutions);

- innovation (degree of S\&T implementation).

Whereas, D.I. Kokurin subdivides the factors into those ones that influence the financial mechanism for innovative development, and external and internal ones. In his opinion, internal factors shape the objective internal cross-institutional relations, featuring the ownership, business and legal structure, size and industry of innovation agent, etc. [2]

E.A. Divaeva points out the following factors of inner substance, scale and pace of changes in the financial mechanism for innovative development [3]:

- renewal and upgrade of products to make them more competitive in the domestic and foreign markets;

- revival of international cooperation in science and technology, promotion to the global market;

- fast implementation and wide proliferation of R\&D results, etc.

\footnotetext{
${ }^{2}$ Definition of the term 'factor'. URL: http://vslovare.ru/slovo/jekonomicheskiij-slovar/faktorjy (In Russ.)
}

In this research factors of the financial potential of corporate innovative development shall mean reasons and conditions for the potential to increase.

Reviewing foreign practices of evaluating the factors that influence the financial potential of corporate innovative development, I should mention the research referred to herein [4]. It states the factors have the following constituents:

- financial;

- S\&T;

- organizational;

- HR;

- production and technology;

- consumption.

However, the above authors do not focus on effects of each constituent.

Ş. Şuşu, M. Birsan [5] claim that the financial potential of corporate innovative development is impacted by:

- strategic priorities of corporate development;

- alternative methods to raise earnings;

- competitive advantages of the entity;

- corporate risks of innovation finance.

The authors of the above approach consider the financial constituent as the central one, believing that sufficient financial resources of the entity will facilitate the development of the other constituents. This is believed to ultimately ignite innovation.

What should be done to evaluate the financial potential of corporate innovative development is identify and analyze factors influencing the innovative development and circulating in global practices [6], with the main ones including the following aspects:

- efficiency of the current economic and financial policy;

- investment and innovative opportunities of the business entity;

- development level of financial institutions (banking, investment, trading, insurance);

- existing taxation principles;

- degree of investment and innovative project risk;

Please cite this article as: Aliev A.A. Factors Influencing the Financial Potential of Corporate Innovative Development. 
- conditions for attracting domestic and foreign investment;

- availability of the State financial aid to innovation, and eligibility conditions;

- regulatory and legislative background;

- profitability of entities, fiscal revenue, etc.

In this respect, the hierarchy of factors influencing corporate innovative development and financial potential [7] should be viewed as a coherent system of global, country and corporate factors.

Global trends in corporate innovative development and corporate innovative capabilities can be traced by analyzing the innovative development of leading countries of the world [8].

1. Considering the innovative sector as the most lucrative in terms of profit and financial risks. According to the global capitalization and profitability rating, Top-10 stocks feature only entities from the same sector, which global investors qualify as fundamentally stable and effective. Constituting the core of the sixth wave of innovation, the innovation sector crowns the top of the pyramid resting upon the national economy and sustainable economic development [9]. This sector drives the economic development, with its needs circumscribing the strategic cooperation with other industries. Financial flows and resources of the hightech sector may become financial resources underlying the financial potential of corporate innovative development.

2. Ceasing to be a theoretical paradigm, the innovative economy morphs into an imperative to create relationships among consumers and producers of goods and services. It becomes a key factor of market relations, foundation for competitiveness of the State and companies.

3. Innovative constituent defines consumer demand for high quality goods and services.

4. Intensifying globalization processes of the global economy are concurrent with the reallocation of free financial resources into highly profitable innovative projects.

5. Growth in revolutionizing innovation dramatically changes the competitive environment of any product, service or type of activity, fostering an increasing supply of new goods and services.

6. Although national economies still depend on energy resources, the 20-20-20 energy strategy gradually rearranges the structural balance, with innovationdriven industry prevailing.

Global trends in innovative development are considered to macroeconomically and strategically reshape the way countries worldwide develop their national economies and companies, bringing innovation to the frontline [10].

According to Ernst \& Young studies ${ }^{3}$, the leading innovative companies have been outperforming innovative companies with the lowest ratings by 16 percent for the recent three years.

Fig. 1 shows the nexus between a long-standing growth of companies and their innovative activities.

As part of the market economy, any structure (private or public) [11] constitutes an open economic system, maintaining its production and business in a consistent country-specific environment. To strengthen its positions nationally and globally, increase the financial sustainability and capabilities, the entity should be in sync with trends in corporate innovative development and finance as they are in advanced economies [2].

Supporting their innovation processes, countries of the world ${ }^{4}$ adhere to national long-term and mid-term strategies for economic and technological advancement $[12,13]$. The countries set up development priorities, financial mechanisms and volume of financial resources earmarked for innovative development [14].

Such strategies are implemented by Japan, Germany, USA, China, Great Britain, Brazil, India and other leaders in innovation and innovative development [12, 13] (Table 1).

The finance of corporate innovative development abroad basically depends on the following factors ${ }^{5}[4,5$, 12-14]:

\footnotetext{
${ }^{3}$ Ernst \& Young. URL: http://www.ey.com/ru/ru/home (In Russ.)

${ }^{4}$ Translator's Note. The author hereinafter refers to countries, other than Russia, comparing it with global trends and practices.

${ }^{5}$ Nekhorosheva L.N., Egorov S.A. Modeli gosudarstvennogo regulirovaniya razvitiya venchurnoi deyatel'nosti: mirovoi opyt i problemy stran [Models of State regulation of venture activity development: Global experience and challenges of the CIS]. URL:

http://iee.org.ua/files/alushta/32-nehorosheva-modeli_gos.pdf (In Russ.)
} 
- investment of budgetary resources in authorized capital of venture capital funds and other specialpurpose financial organizations involved into corporate innovative development;

- tax benefits to innovative companies;

- granting beneficial public loans and guarantees (insurance) to innovative-driven companies;

- implementation of special-purpose governmental programs for procurement of innovative goods and services;

- finance of technological parks, business incubators and other targets of innovative development.

The Russian economy is impacted by similar factors of corporate innovative development, financial capabilities for innovation and their increase ${ }^{6}$.

The finance of corporate innovative development and increase in financial capabilities are currently subject to the following factors:

- financial aid at initial, preparatory steps of innovation. The mechanism is deployed, to a certain extent, in State-financed programs for supporting small innovative businesses;

- setting up mechanisms to involve innovative companies and private business in outlining and implementing innovative development policies based on the Public-Private Partnership model, and mechanisms for financial support of such alliances, associations and companies.

However, this will definitely not suffice. Evaluating innovative activities of the Russian entities, I should admit that their innovative development [14] significantly falls behind that of companies operating in advanced countries. Hence Russia unavoidably has to import knowledge-intensive goods and technologies (Table 2).

Table 2 reflects considerable differences between companies' motivation for developing innovative activity. There are fewer technological innovators in Russia than in Germany, Sweden, Italy and Finland, accounting for a 400-percent difference on average.

\footnotetext{
${ }^{6}$ Kharin A.A., Kolenskii I.L. Upravlenie innovatsiyami: v 3-kh kn. Kniga 1. Osnovy organizatsii innovatsionnykh protsessov [Innovation management: Three books. Book One. Organizational principles of innovation processes]. Moscow, Vysshaya shkola Publ., 2003, 252 p.
}

The Russian companies manufacture an incommensurately lower percentage of innovative industrial goods than the Western ones. Thus, despite being financially capable, the Russian industrial sector is not motivated for active innovative development.

The Russian companies are reluctant to invest and innovate [15] since the corporate sector's innovation is subject to financial restrictions, thus making innovative development economically unattractive for many Russian companies. What impedes the finance is unstable economic development of Russia, sectoral economic sanctions of the Western countries, limited information on rival innovative projects. High uncertainty risks of corporate innovation extend the payback period of such projects and raise the benchmark rate of return (Table 3).

Whereas, many Russian companies treat innovation as an important success factor, striving to develop and unlock their innovative potential. Table 4 indicates the significance of innovative development for companies.

The following features are common for active innovators, which take the lead in innovative development:

- purposeful innovative activity;

- clear strategy for innovative development;

- view of innovation management as an important business function; well organized innovation process at the corporate level;

- innovative goods accounting for a high percentage of revenue and net profit;

- venture capital financing for purposes of innovative project development.

As the research reveals, financial results of the leading foreign and Russian companies mainly depend on their innovative development strategies and financial constituents, first of all. Following its financial strategy, the company shall choose and make the most effective financial investment in order to increase its financial potential for corporate innovative development, ensure a continuous growth in capitalization, reaffirm its competitive advantages nationwide and worldwide. Concurring with their long-term investment policy,

Please cite this article as: Aliev A.A. Factors Influencing the Financial Potential of Corporate Innovative Development. 
the financial strategy is supposed to help companies attain their long-term development goals.

The sound and adopted financial strategy for corporate innovative development is to clarify financial sources of innovative projects, internal rate of return (IRR) and payback period. These indicators tend to be 12 percent and 5 years respectively in advanced countries. However, these criteria appear to be higher in Russia since innovative projects are exposed to high risks there. Hence the main focus is put on innovative projects with the high rate of return and short payback period. The majority of the Russian companies (60 percent) invest from 6 to 20 percent of their net profit in innovative projects, while companies from advanced countries earmark about 25-35 percent of their net profit for innovative projects. Revenue is one of the sources the Russian companies use to finance their innovative development, while innovative programs are the main driver of revenue in advanced countries. Revenue and net profit inter alia influence the innovative development of the Russian companies. According to Ernst \& Young experts, innovation will absorb from 15 to 25 percent of the Russian companies' revenue within the coming five years. On the other hand, innovative activity of the European companies will help ensure a 61-100 percent growth in their revenue [16].

It is important to note that the financial strategy of the company necessitates substantial financial resources to be drawn from special-purpose (venture capital) funds. These are such financial resources that used to feed innovative projects of active innovators, such as Apple Computers, Microsoft, Sun Microsystems, Intel [17]. Currently, many medium-sized innovative companies resort to venture capital in order to implement innovative R\&D [18].

Russia sees the first instances of innovative projects funded by major venture capital funds and supported by their financial and organizational capabilities.
Fig. 2 depicts my own approach to setting a system of factors influencing the financial potential of corporate innovative development.

To make dramatic rearrangements in venture capital financing of corporate innovative development in Russia, the favorable investment environment should be created. There should be a regulatory and legislative framework and mechanisms to insure venture capital financing of the Russian companies' innovative projects.

Scrutinizing the factors influencing the potential for corporate innovative development, I make up a system of global, country and corporate factors (Fig. 3).

Therefore, as the research shows, the State aid fosters the highest upsurge in innovative activities in the Russian market. Despite the existing global trends and opportunities for the Russian companies, private organizations fail to actively finance and promote promising innovations due to an underdeveloped tax incentive mechanism for innovative development, lending to investment and innovative projects, high risks associated with the innovation policy.

Having examined how corporate investment development is financed in the Western countries, I found out that robust financial institutions, taxation and venture capital financing of corporate innovative development and subsequently lower risks allow companies to invest in their innovation, treating it as an important business function. Hence profit from innovative goods and services account for a substantial percentage of revenue. These facts contributed to the system of factors influencing the financial potential of corporate innovative development. Based on the system, innovation-driven companies will be able to detect drawbacks in their financial policies for innovative development and adjust it, thus forming the adequate financial potential for financing the innovative development. 


\section{Table 1}

Measures to support innovative development in developed countries

\begin{tabular}{ll}
\hline Supportive measures & Country \\
\hline Financial backing to joint ventures of business structures and research institutions & USA, Germany, Sweden, Denmark, United Kingdom \\
\hline Incentives for SMEs to use innovative technology & USA, China, France, United Kingdom \\
\hline Financial backing to development of technological parks and technological incubators & Denmark, Germany, India, Sweden, China \\
\hline $\begin{array}{l}\text { Setting and implementing the methods for direct financial backing to innovative production } \\
\text { enterprises (grants, loans on beneficial terms) }\end{array}$ & United Kingdom, Germany, France, India, China, \\
\hline Financial backing to venture capital funds and companies in the innovation sector & Denmark, Norway, USA \\
\hline Tax incentives to innovative companies & Sweden, Norway, Germany, India \\
\hline Venture capital financing of corporate innovative development & Norway, France, Germany, Spain \\
\hline
\end{tabular}

Source : $[4,5,12-14]$

\section{Table 2}

Innovative activity of Russian and foreign companies, percentage

\begin{tabular}{llllll}
\hline Metrics & Russia & Germany & Sweden & Italy & Finland \\
\hline $\begin{array}{l}\text { Companies implementing technological } \\
\text { innovation out of total companies in } \\
\text { the industrial and servicing sectors }\end{array}$ & 9.7 & 60.9 & 36.3 & 44.8 & 46.8 \\
\hline $\begin{array}{l}\text { Innovative industrial products out of total } \\
\text { industrial products }\end{array}$ & 0.5 & 7.1 & 18.7 & 27.2 & - \\
\hline
\end{tabular}

Source : Decree of the Government of the Russian Federation On the Concept of Long-Term Socio-Economic Development of the Russian Federation up to 2020 of November 17, 2008 № 1662-p; Ministry of Economic Development of the Russian Federation. URL: http://www.ved.gov.ru/ (In Russ.)

Table 3

Sources and criteria of corporate innovation financing

\begin{tabular}{llll}
\hline Sources of finance & Benchmark RR, \% & $\begin{array}{l}\text { Lead time } \\
\text { of investment, year }\end{array}$ & Key financing tools \\
\hline Business angels. Governmental foundations & $>40$ & $3-7$ & $\begin{array}{l}\text { Personal funds, special-purpose } \\
\text { governmental programs }\end{array}$ \\
\hline Venture capital funds & $30-40$ & $3-5$ & Venture capital \\
\hline Direct investment funds. Bank lending & $20-30$ & $1-2$ & $\begin{array}{l}\text { Venture capital, resources of the fund, } \\
\text { bank loans }\end{array}$ \\
\hline $\begin{array}{l}\text { Foundations for promising researches. } \\
\text { Issue of stocks }\end{array}$ & $10-20$ & $1-2$ & Resources of the fund, equity \\
\hline
\end{tabular}

Source : [17]

\section{Table 4}

Importance of innovative development for companies in 2016, and the 2020 forecast, percent

\begin{tabular}{lllll}
\hline \multirow{2}{*}{ Degree of importance } & \multicolumn{2}{l}{ Roreign companies } & $\mathbf{2 0 1 6}$ & $\mathbf{2 0 2 0}$ \\
\cline { 2 - 5 } & $\mathbf{2 0 1 6}$ & $\mathbf{2 0 2 0}$ & 0 & 0 \\
\hline Not important & 2 & 1 & 0 & 0 \\
\hline Not very important & 3 & 3 & 8 & 7 \\
\hline Ambiguous & 11 & 37 & 30 & 20 \\
\hline Rather important & 40 & 51 & 62 & 73 \\
\hline Motivated by competition & 43 &
\end{tabular}

Source : Ernst \& Young. URL: http://www.ey.com/ru/ru/home (In Russ.) 


\section{Figure 1}

Relationship between a long-term growth of companies and their innovative activities from 2014 to 2018, percentage

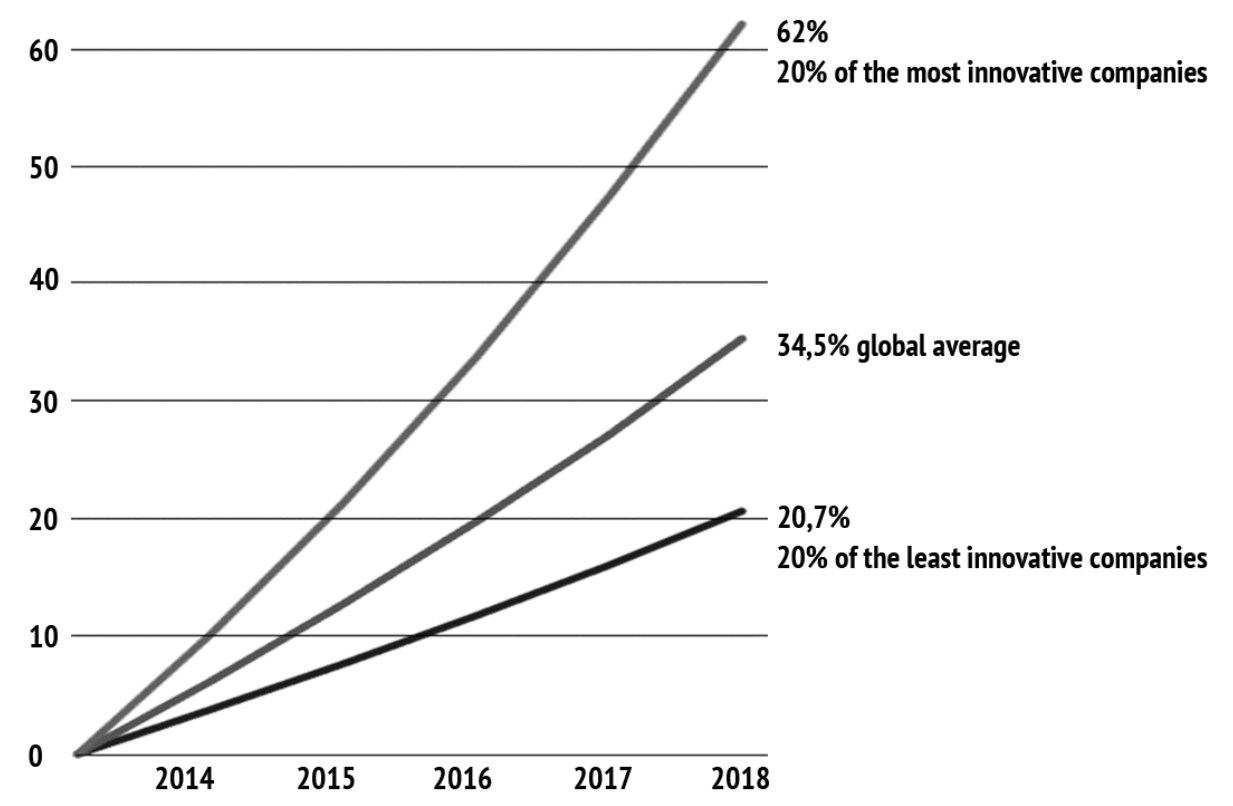

Source : Ernst \& Young. URL: http://www.ey.com/ru/ru/home (In Russ.)

\section{Figure 2}

An approach to shaping a system of factors influencing the cost-effective solutions related to corporate innovative development

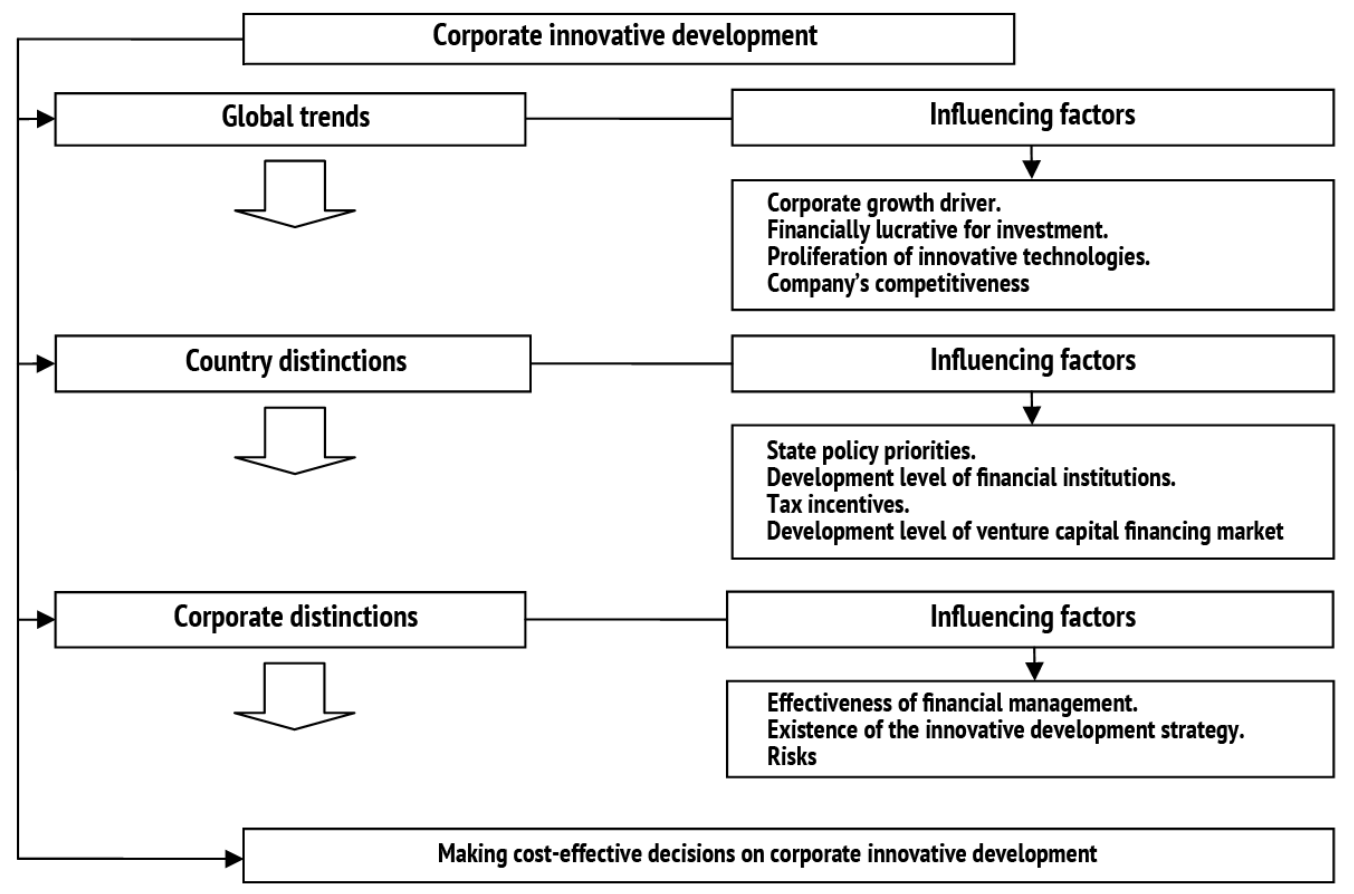

Source : Authoring

Please cite this article as: Aliev A.A. Factors Influencing the Financial Potential of Corporate Innovative Development. Digest Finance, 2018, vol. 23, iss. 2, pp. 163-171. https://doi.org/10.24891/df.23.2.163 


\section{Figure 3}

A system of factors influencing the financial potential of corporate innovative development

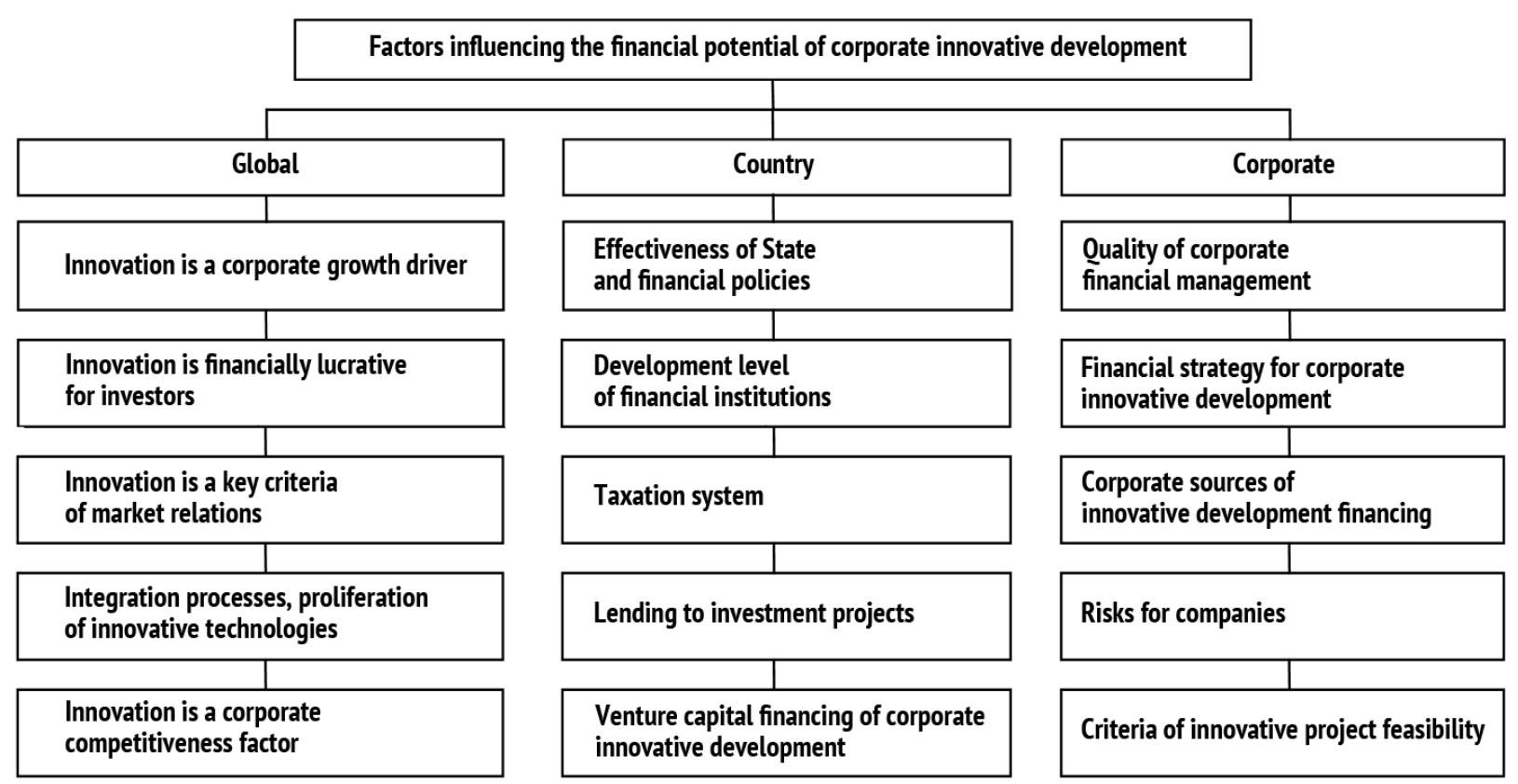

Source : Authoring

\section{References}

1. Zenchenko S.V., Shemetkina M.A. [Investment potential of the region]. Sbornik nauchnykh trudov SevKavGTU. Ser.: Ekonomika = Scientific Papers of North Caucasian State Technical University. Series Economics, 2007, no. 6, pp. 142-148. (In Russ.)

2. Kokurin D. [Public funding of innovation activities]. Finansovyi biznes = Financial Business, 2000, no. 11-12, pp. 37-40. (In Russ.)

3. Divaeva E.A. Osnovy otsenki urovnya innovatsionnogo potentsiala i otsenka ego urovnya: monografiya [Innovative capacity: Basic principles and assessment: a monograph]. Moscow, Paleotip Publ., 2007, 144 p.

4. Boian N., Boian M.A. The Diagnosis of Financial Resources of Small and Middle Size Enterprises (SME). Proceedings in Manufacturing Systems, 2013, vol. 8, iss. 4, pp. 221-226.

5. Şuşu Ş., Birsan M. The Financial Diagnosis - Component of the Global Diagnosis and Instrument of the Financial Analysis. The Annals of Dunarea de Jos University of Galati, 2009, no. 2, pp. 271-280. URL: http://www.ann.ugal.ro/eco/Doc2009_2/Susu_Birsan.pdf

6. Karpenko O.A. [Sources of financing innovation enterprise]. Kreativnaya ekonomika = Journal of Creative Economy, 2014, no. 7, pp. 40-47. (In Russ.)

7. Sinel'shchikova N.V., Gromova E.I., Keri I.T. [The role of innovations in providing finance security of companies]. Vestnik Rossiiskogo ekonomicheskogo universiteta imeni G.V. Plekhanova = Vestnik of Plekhanov Russian University of Economics, 2015, no. 3, pp. 31-36. (In Russ.)

8. Ekimova K.V., Aliev A.A. [About the methodology of assessing the financial potential of innovative development (on the example of the leading companies in the oil and gas industry)]. Obshchestvo $i$ ekonomika= Society and Economics, 2016, no. 1, pp. 30-36. (In Russ.) 
9. Ordov K.V. [Interaction of innovations and capitalization of companies]. Slavyanskii forum = Slavic Forum, 2014, no. 1, pp. 319-323. (In Russ.)

10. Kuz'minykh N.A. [Approaches to assessment of results of innovative development]. Vestnik SamGU = Vestnik of Samara State University, 2011, no. 3, pp. 47-48. (In Russ.)

11. Tret'yakova E.V., Sharkova A.V. [Financial infrastructure supporting innovative business]. Nauchnoissledovatel'skii finansovyi institut. Finansovyi zhurnal = Financial Research Institute. Financial Journal, 2011, no. 3, pp. 113-126. (In Russ.)

12. Poolton J., Ismail H. New Developments in Innovation. Journal of Managerial Psychology, 2000, vol. 15, no. 8, pp. 795-811.

13. Barge-Gil A., Lopes A. R versus D: Estimating the Differentiated Effect of Research and Development on Innovation Results. Industrial and Corporate Change, 2015, vol. 24, iss. 1, pp. 93-129. URL: https://doi.org/10.1093/icc/dtu002

14. Fedosov P.E. [On deformed structure of modern Russian economy]. Sibirskii torgovo-ekonomicheskii zhurnal = Siberian Trade and Economic Journal, 2016, no. 1, pp. 6-14. (In Russ.)

15. Baurina S.B., Darbisheva P.G. [The role of the State in innovative economy development]. Innovatsii: perspektivy, problemy, dostizheniya: materialy III Mezhdunarodnoi nauchno-prakticheskoi konferentsii [Proc. 3rd Int. Sci. Conf. Innovation: Prospects, Problems, Achievements]. Moscow, Plekhanov Russian University of Economics Publ., 2015, pp. 5-7.

16. Kashirin A., Semenov A. Venchurnoe investirovanie v Rossii [Russian venture investment]. Moscow, Vershina Publ., 2007, 331 p.

17. Zaitsev A.V. [Venture capital financing of innovative projects at high-tech enterprises]. Rossiiskoe predprinimatel'stvo = Russian Journal of Entrepreneurship, 2011, no. 5, pp. 30-34. (In Russ.)

18. Ishina I.V., Dolina O.N. [Financial policy in the field of innovation: International dimension]. Audit i finansovyi analiz = Audit and Financial Analysis, 2014, no. 6, pp. 309-311. (In Russ.)

\section{Conflict-of-interest notification}

I, the author of this article, bindingly and explicitly declare of the partial and total lack of actual or potential conflict of interest with any other third party whatsoever, which may arise as a result of the publication of this article. This statement relates to the study, data collection and interpretation, writing and preparation of the article, and the decision to submit the manuscript for publication. 